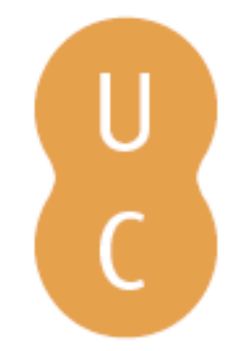

\title{
pommalina
}

\section{Effect of prescribed burning on chlorophyll fluorescence and sap flow of Pinus laricio, a preliminary study}

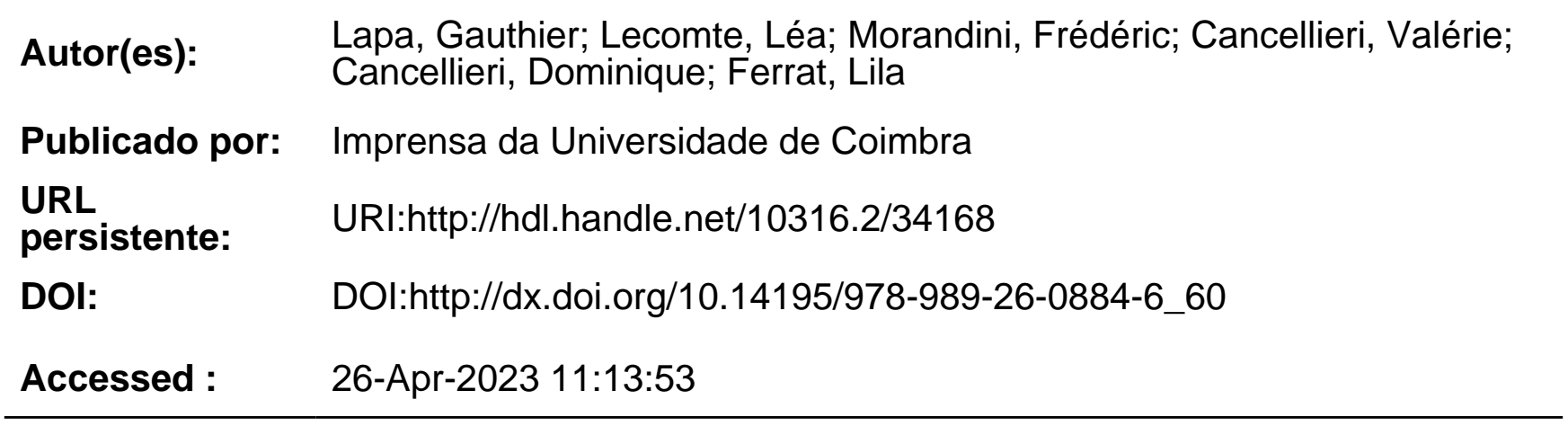

A navegação consulta e descarregamento dos títulos inseridos nas Bibliotecas Digitais UC Digitalis, UC Pombalina e UC Impactum, pressupõem a aceitação plena e sem reservas dos Termos e Condições de Uso destas Bibliotecas Digitais, disponíveis em https://digitalis.uc.pt/pt-pt/termos.

Conforme exposto nos referidos Termos e Condições de Uso, o descarregamento de títulos de acesso restrito requer uma licença válida de autorização devendo o utilizador aceder ao(s) documento(s) a partir de um endereço de IP da instituição detentora da supramencionada licença.

Ao utilizador é apenas permitido o descarregamento para uso pessoal, pelo que o emprego do(s) título(s) descarregado(s) para outro fim, designadamente comercial, carece de autorização do respetivo autor ou editor da obra.

Na medida em que todas as obras da UC Digitalis se encontram protegidas pelo Código do Direito de Autor e Direitos Conexos e demais legislação aplicável, toda a cópia, parcial ou total, deste documento, nos casos em que é legalmente admitida, deverá conter ou fazer-se acompanhar por este aviso.

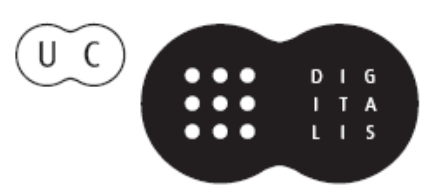




\section{ADVANCES IN}

Forest Fire

\section{RESEARCH}

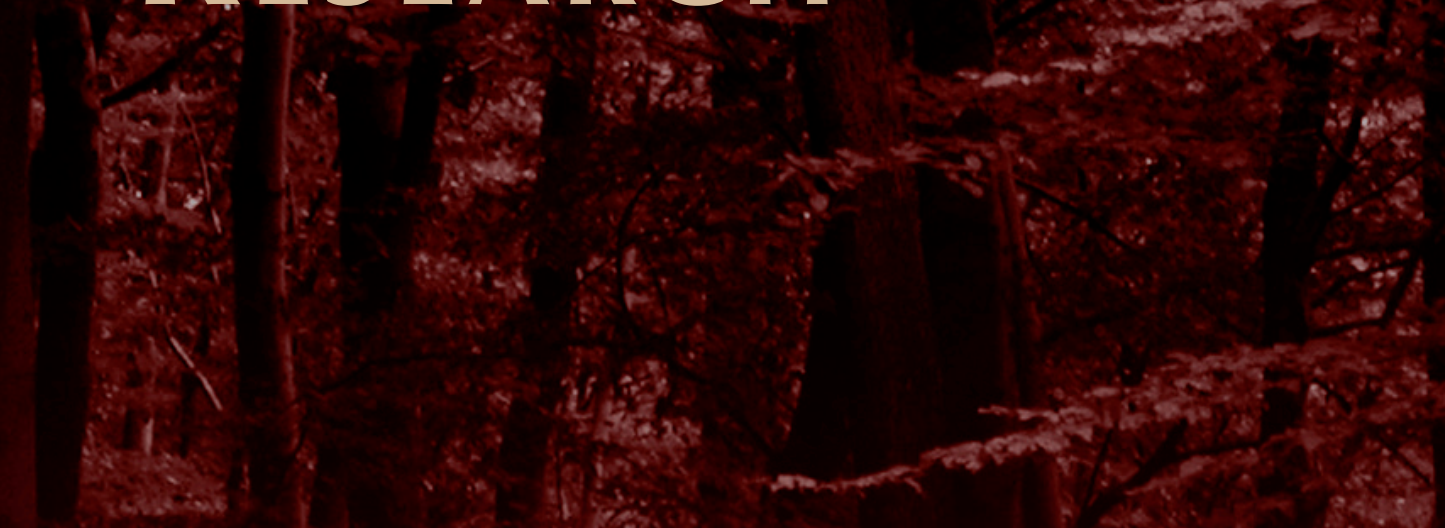

\section{DOMINGOS XAVIER VIEGAS}

\section{EDITOR}




\title{
Effect of prescribed burning on chlorophyll fluorescence and sap flow of Pinus laricio, a preliminary study
}

\author{
Lapa Gauthier, Lecomte Léa, Morandini Frédéric, Cancellieri Valérie, Cancellieri Dominique, Ferrat \\ Lila
}

UMR CNRS SPE 6134, Université de Corse, 20250 Corte, France, lapa@univ-corse.fr,

lecomtelea10@gmail.com, morandin@univ-corse.fr,vcancellieri@univ-corse.fr, cancelie@univ-

corse.fr,ferrat@univ-corse.fr

\begin{abstract}
Forest fires constitute important perturbations in Mediterranean ecosystems, and preventing methods are used (e.g. prescribed burning) to avoid large scale fires during dry periods. This preliminary study aims to investigate the effects of prescribed burning on Corsican pine (Pinus nigra ssp. laricio (Poir.) Maire var. corsicana (Loud.) Hyl.) in field conditions. Two complementary approaches were tested: chlorophyll fluorescence and sap flow measurements. Chlorophyll fluorescence parameters allowed showing short term effects of prescribed burning, with a decrease of photochemical process on burned pines. However, at medium term, no significant difference was visible between burned and reference trees. Sap flow monitoring provided information about daily and seasonal cycles, it was greatly correlated with vapour pressure deficit, but no effect of prescribed burning was observed.
\end{abstract}

Keywords: Prescribed burning, Pinus laricio, chlorophyll fluorescence, sap flow

\section{Introduction}

Forest fires constitute one of the major perturbations for Mediterranean ecosystems, with real human, economic and ecological hazard. Mediterranean pines are well known for their flammability and their vulnerability to natural fires, and in Corsica (France), in order to prevent large scale fires and protect forests, prescribed burning are conducted under Corsican pine forests (Pinus nigra ssp. laricio (Poir.) Maire var. corsicana (Loud.) Hyl.). Today, a scientific framework is asked by forest managers to help guide this practice.

Previous studies (Ferrat et al. 2009; Cannac et al. 2009, 2011) brought beginnings of answers with laboratory experiments on needles and experimental fires in nursery, and it is now necessary to go on with tools that can be used on the field. The aim of this preliminary study is to test the potentialities of some vitality/stress indicators in quantifying impacts of a prescribed burning in a natural pine stand: chlorophyll fluorescence and sap flow measurements.

Chlorophyll fluorescence is widely used in plant physiological studies due to the ease of the field measurements and the quality of information provided. Indeed, changes of chlorophyll fluorescence are correlated with changes of $\mathrm{CO}_{2}$ assimilation and therefore with changes of photosynthetic rate (Baker 2008), it is also a good indicator of stress (Peñuelas et al. 1998). Three parameters are usually monitored, the quantum yield photosystem II (ФPSII), the maximum quantum yield of PSII ( $\left.\mathrm{F}_{\mathrm{v}} / \mathrm{F}_{\mathrm{m}}\right)$ and the non-photochemical quenching (NPQ). The first are indicators of photochemical process: $\Phi P S I I$ corresponds to the proportion of absorbed light used in photochemistry, and $F_{v} / F_{m}$ is an indicator of photosynthetic performance, with optimal value around 0.83 , lower value indicating a photoinhibition. NPQ is correlated to energy dissipated as heat and is studied as a mechanism of protection (Maxwell and Johnson 2000; Calatayud et al. 2006; Baker 2008).

These parameters are influenced by soil mineral content (Laing et al. 2000; Shangguan et al. 2000; Gough et al. 2004) and by drought (Shangguan et al. 2000; Pukacki and Kamińska-Rożek 2005; 
Boureima et al. 2012), as demonstrated on coniferous and crop plants. They also undergo important seasonal variations (Vogg et al. (1998); Gielen et al. (2000) on coniferous; and Damesin (2003) on deciduous trees).

Sap flow is widely used to measure whole tree water use, due to its high degree of reliability and accuracy (Lu et al. 2004). Many studies have investigated effects of abiotic parameters on sap flow, mainly drought, with disparate results depending on the species considered (Anfodillo et al. 1998 for pinaceae). It is greatly influenced by climatic conditions (radiation, rain, VPD...) on different coniferous (Köstner et al. 1996; Simpson 2000; Iijima et al. 2004) and deciduous trees (Zalesny Jr et al. 2006; Nasr and Mechlia 2007). Ducrey et al. (1996), highlighted an alteration of sap flow after an important experimental heating of young Pinus halepensis trunk.

To our knowledge, literature regarding the effect of prescribed burning with chlorophyll fluorescence and sap flow on a natural pines stands is quite poor (Ducrey et al. 1996; Ferrat et al. 2009; Pasqualini et al. 2009) and generally realized experimentally and for short periods.

\section{Methods}

\subsection{Study site}

The study site was a mountain (900 m a.s.l.) natural pure Corsican pine stand situated in the Venaco Forest, Corsica, France (42 $\left.11^{\prime} 51.3^{\prime \prime N} 9^{\circ} 06^{\prime} 53.5^{\prime \prime E}\right)$. Trees were $20-25$ years old, $11-17 \mathrm{~m}$ tall, with 13.5-18.5 cm DBH in average. Prescribed burning was performed March 29, 2012 on an usual fuel load surface (pine needles bed) of about 1500 g. $\mathrm{m}^{-2}$, leading to a fire intensity between 50 and 100 kW.m ${ }^{-1}$ (Trabaud 1979; Ferrat et al. 2011).

Measurements of chlorophyll fluorescence and sap flow were realised daily, then monthly, on burned and reference (unburned) trees.

\subsection{Chlorophyll fluorescence}

Measurements of chlorophyll fluorescence were realised in situ on attached needles of the previous year with a Portable Chlorophyll Fluorometer (PAM-21000, Walz, Germany), needles were darkadapted during 30 minutes before measurement to open the reaction centres of the PSII. All of these measurements were realised at the sunrise, before the burning and daily then monthly after the burning, from March 27 to July 13, 2012. When light energy is absorbed by chlorophyll, the light not used in photosynthesis is dissipated as heat or is re-emitted as light fluorescence. Chlorophyll fluorescence is measured by exposing a leaf to light and measuring light re-emitted, different intensity/flash of light is used to measuring different parameters (figure 1). Measurement light (MB) allows measurement of the zero fluorescence level $\left(\mathrm{F}_{\mathrm{o}}\right)$, the maximum fluorescence level $\left(\mathrm{F}_{\mathrm{m}}^{\mathrm{o}}\right)$ is measured after a saturating flash (SP), a second saturating flash is applied under an actinic light (AL) to measuring the maximum fluorescence in the light $\left(\mathrm{F}_{\mathrm{m}}\right)$ and the fluorescence level under actinic light, before the second flash $\left(F_{t}\right)$, the zero level fluorescence $\left(F^{\prime}{ }_{0}\right)$ is measured under far-red light (Maxwell and Johnson 2000). 


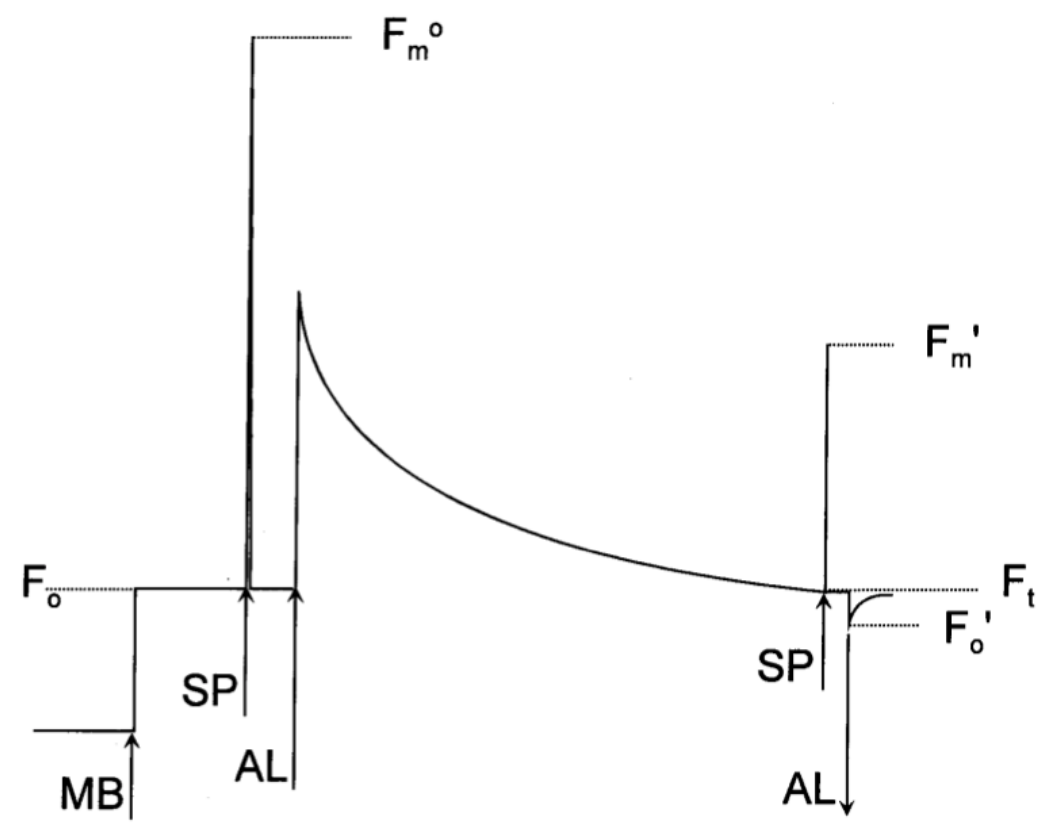

Figure 1. Sequence of a typical fluorescence trace (from Maxwell and Johnson 2000).

Three parameters were monitored: the quantum yield of photosystem II (ФPSII), the maximum (or intrinsic) quantum yield of photosystem II $\left(\mathrm{F}_{\mathrm{v}} / \mathrm{F}_{\mathrm{m}}\right)$ and the non-photochemical quenching. These parameters were calculated according to Maxwell and Johnson (2000), i.e.:

$$
\begin{gathered}
\text { DPSII }=\frac{\left(F_{m}^{\prime}-F_{t}\right)}{F^{\prime}{ }_{m}} \\
F_{v} / F_{m}=\frac{\left(F_{m}^{o}-F_{o}\right)}{F^{o}{ }_{m}} \\
N P Q=\frac{\left(F_{m}^{o}-F_{m}^{\prime}\right)}{F_{m}^{\prime}}
\end{gathered}
$$

with $\mathrm{F}^{\prime}{ }_{\mathrm{m}}$ is the maximum fluorescence in the light, Ft is the level of fluorescence before the second saturating flash, $\mathrm{F}_{\mathrm{m}}^{\mathrm{o}}$ is the maximum fluorescence from dark-adapted leaves.

\subsection{Sap flow}

Sap flow measurements were realised with thermal dissipation probes (TDP, Dynamax, USA) according to the method developed by Granier (Granier 1985; Granier and Gross 1987). This method is based on temperature differences between two probes inserted radially into the trunk. The upper probe is continuously heated, both probes have a thermocouple. When sap flow is null, the difference between the two probes is maximal, when sap flow is high it dissipates heat produced by the upper probe by convection, and the difference of temperature between the two probes will depend on the speed of sap (Granier 1985; Granier and Gross 1987). 
Depending on the thickness of sapwood, two length of probes were used (30 for DBH between 13.5 and $14.5 \mathrm{~cm}$ and $50 \mathrm{~mm}$ for DBH between 15.5 to $18.5 \mathrm{~cm}$ ) to improve the measurement (Lu et al. 2004). All probes were installed at East to avoid the influence of azimuth (Do and Rocheteau 2002). These measurements were recorded continuously before and after the burning from March 28 to October 30, 2012. Data were recorded in a CR3000 Micrologger (Campbell Scientific, USA) supplied by a battery charged by a solar panel. Together relative humidity and temperature were monitored, these allow computation of vapour deficit pressure (VPD, in $\mathrm{kPa}$ ):

$$
\begin{gathered}
V P D=e_{s}-e_{a} \\
e_{s}=0.6108 \times e^{\left(\frac{17.27 \times T}{T+273.3}\right)} \\
e_{a}=e_{s} \times \frac{R H}{100}
\end{gathered}
$$

with $\mathrm{e}_{\mathrm{s}}$ is the saturation vapour pressure $(\mathrm{kPa}), \mathrm{e}_{\mathrm{a}}$ is the actual vapour pressure $(\mathrm{kPa}), \mathrm{T}$ is the temperature $\left({ }^{\circ} \mathrm{C}\right)$ and $\mathrm{RH}$ is the relative humidity $(\%)$.

Sap flow were calculated according to Granier and Gross (1987):

$$
\begin{gathered}
k=\frac{\Delta T M-\Delta T}{\Delta T} \\
V=0.0119 \times k^{1.231}
\end{gathered}
$$

with $\mathrm{k}$ is a dimensionless number, $\Delta \mathrm{TM}$ is the maximal temperature difference between the two probes $\left({ }^{\circ} \mathrm{C}\right), \Delta \mathrm{T}$ is the temperature difference between the two probes $\left({ }^{\circ} \mathrm{C}\right)$ and $\mathrm{V}$ is the sap velocity $\left(\mathrm{cm} \cdot \mathrm{s}^{-1}\right)$.

\section{Results - Discussion}

The prescribed burning influenced all chlorophyll fluorescence measurements at short term, the maximum quantum yield of burned pines decreased strongly immediately after the burning, from 0.84 to 0.76 . It increased few days later but remained always under the reference values (resp. 0.82 vs. 0.84 during summer). $\mathrm{F}_{\mathrm{v}} / \mathrm{F}_{\mathrm{m}}$ of the reference pines remained constant during the entire measurement period (approx. 0.84, figure 2).

Quantum yield increased the day after the burning, from 0.22 to 0.37 (68\% up), but there was no difference between burned and reference pines few days later. Furthermore, this parameter underwent seasonal variations with a peak (0.44) at the end of May (figure 3).

Non-photochemical quenching decreased 2 and 3 days after the burning, from 2.3 to 1.2 (48\% down) then increased to the initial value the 4 th day. Later, it was under the reference $(65 \%$ of the reference value, May, 5), except for the last record (figure 4). 
The decrease of $F_{v} / F_{m}$ immediately after the burning could reveal an alteration of photosynthetic performances due to a thermal stress. Previous study (Pasqualini et al. 2009) showed a decrease of this parameter after a burning on Pinus laricio needles, but this decrease did not have any effect on the survival of populations. It was shown that $\mathrm{F}_{\mathrm{v}} / \mathrm{F}_{\mathrm{m}}$ was not long term affected if the value was kept upper than $60 \%$ of reference value (Ferrat et al. 2009), it is in accordance with our results, as Fv/Fm was about $98 \%$ of the reference value at the end of the experiment while it was about $90 \%$ of the reference value 2 days after the burning. NPQ corresponds to energy dissipated at heat, its increase would be a protection mechanism to dissipate energy excess and photo damage of PSII (Calatayud et al. 2006), this mechanism has not been implemented here. In the medium term, none of these three parameters seemed significantly affected by the burning.

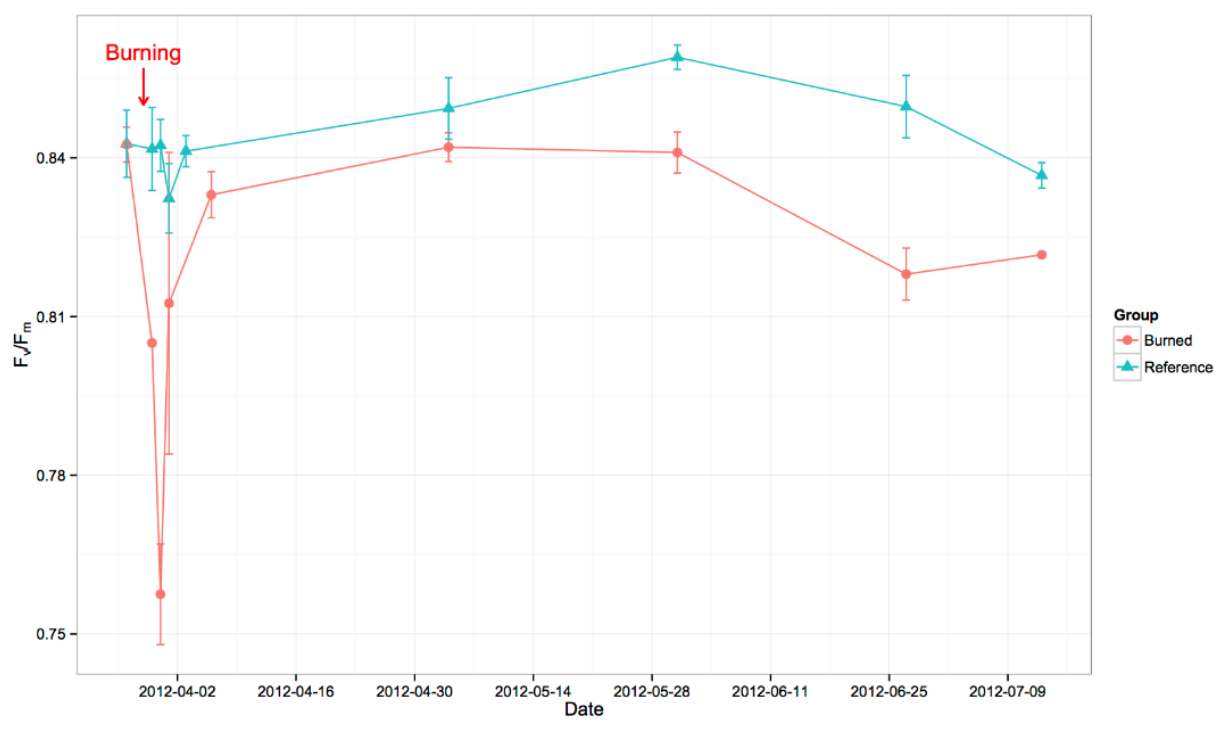

Figure 2. $F_{v} / F_{m}$ for burned and reference pines. Means \pm standard error.

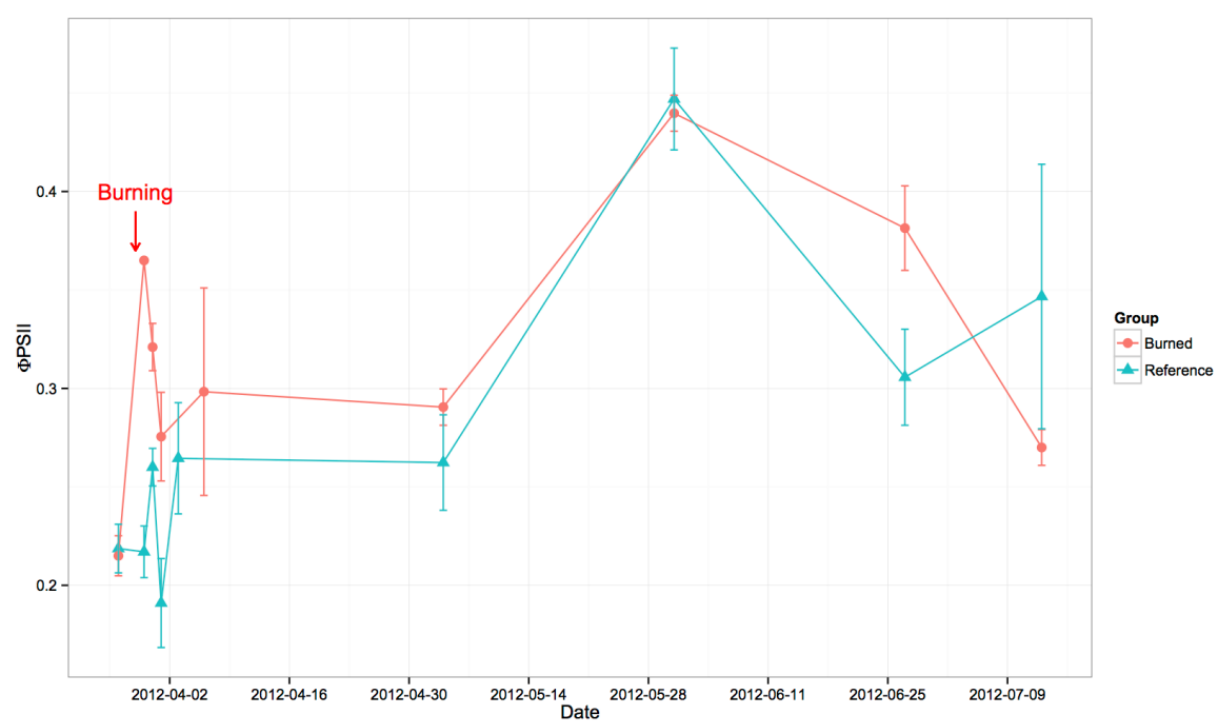

Figure 3. ФPSII for burned and reference pines. Means \pm standard error. 


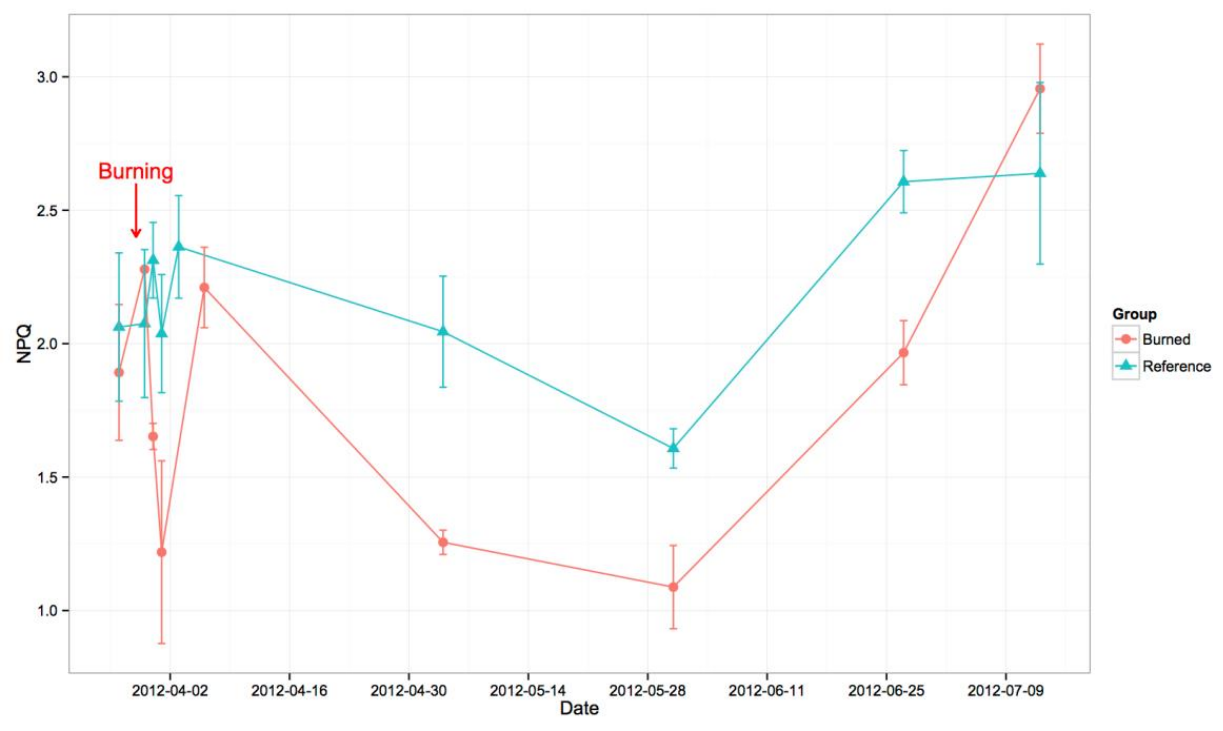

Figure 4. NPQ for burned and reference pines. Means \pm standard error.

Figure 5 shows the sap velocity for two representative trees (a burned and a reference) and the VPD. Sap flow of reference tree was lightly under the sap flow of burned tree during spring (mean: $7.810^{-4}$ cm.s ${ }^{-1}$, max: $4.3910^{-3} \mathrm{~cm} . \mathrm{s}^{-1}$ for reference; mean: $110^{-3} \mathrm{~cm} . \mathrm{s}^{-1}$, max: $6.310^{-3} \mathrm{~cm} . \mathrm{s}^{-1}$ for burned) and summer (mean: $6.510^{-4} \mathrm{~cm} . \mathrm{s}^{-1}$, max: $4.510^{-3} \mathrm{~cm} . \mathrm{s}^{-1}$ for reference, mean: $8.510^{-4} \mathrm{~cm} . \mathrm{s}^{-1}$, max: $4.810^{-}$ ${ }^{3} \mathrm{~cm} . \mathrm{s}^{-1}$ for burned). During autumn they were close (mean: $4.710^{-4} \mathrm{~cm} \cdot \mathrm{s}^{-1}$, max: $2.210^{-3} \mathrm{~cm} \cdot \mathrm{s}^{-1}$ for reference, mean: $410^{-4} \mathrm{~cm} \cdot \mathrm{s}^{-1}$, max: $2.910^{-3} \mathrm{~cm} \cdot \mathrm{s}^{-1}$ for burned). The global sap flow difference between reference and burned tree can be explained by difference of DBH (resp. $14 \mathrm{~cm}$ vs. $15 \mathrm{~cm}$ ) and mainly by difference of probe length (resp. $30 \mathrm{~mm}$ vs. $50 \mathrm{~mm}$ ). It will be important in further studies to homogenize probes for a better discrimination of sap flow trends.

Nevertheless, it can be noticed that sap flow of reference and burned trees had similar variation from the start to the end of the monitoring, the prescribed burning did not seem to affect sap flow.

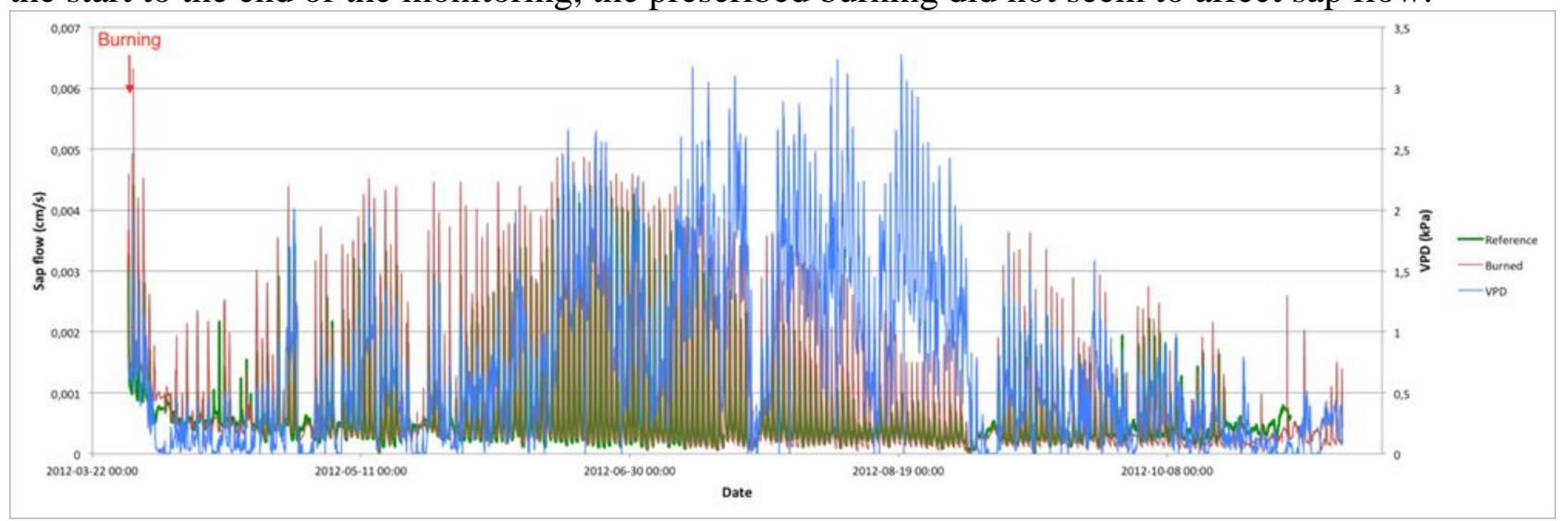

Figure 5. Sap flow velocity for burned and reference pines, and VPD.

The VPD varied daily and seasonally, it was low during spring (mean: $0.47 \mathrm{kPa}$, max: $2.66 \mathrm{kPa}$ ) and greater during summer (mean: 1.19, $\max : 3.27 \mathrm{kPa}$ ) and decreased during autumn (mean: $0.26 \mathrm{kPa}$, max: $1.58 \mathrm{kPa}$ ). Daily and seasonally variation of VPD can be explained by the great influence of relative humidity $(\mathrm{RH})$ on the calculation, indeed during night and rain period $\mathrm{RH}$ is very high and thus VPD is very low. Temperature influences also VPD, more the temperature is important, more the saturation pressure is important and more the VPD may be important (Allen et al. 1998). 
These data show that sap flow was greatly correlated, daily and seasonally, with vapour pressure deficit (VPD). An exception was measured during July and August, with a decrease of sap flow (from 0.004 to $0.002 \mathrm{~cm} . \mathrm{s}^{-1}$ ) while VPD was very high (over $3 \mathrm{kPa}$ ), this drop could be explained by low water availability during drought period (Anfodillo et al. 1998), and would reveal a water saving behaviour (Anfodillo et al. 1998; Badalotti et al. 2000). It will be interesting to survey this behaviour in case of severe drought.

This preliminary study has provided the beginnings of a reply regarding the effect of prescribed burning on photosynthetic and hydric parameters, and also provided information on daily and/or seasonal variation of these parameters. Chlorophyll fluorescence and sap flow measurements are promising tools to evaluate the impact of thermal stress on field, at short, medium and long term. A longer study with more replicate and complementary tools is in progress to provide more accurate answers.

\section{References}

Allen RG, Pereira LS, Raes D, Smith M, others (1998) 'Crop evapotranspiration-Guidelines for computing crop water requirements-FAO Irrigation and drainage paper 56.' (Rome, Italy)

Anfodillo T, Rento S, Carraro V, Furlanetto L, Urbinati C, Carrer M (1998) Tree water relations and climatic variations at the alpine timberline: seasonal changes of sap flux and xylem water potential in Larix decidua Miller, Picea abies (L.) Karst. and Pinus cembra L. Annales des Sciences Forestières 55(1-2), 159-172. doi:10.1051/forest:19980110.

Badalotti A, Anfodillo T, Grace J (2000) Evidence of osmoregulation in Larix decidua at Alpine treeline and comparative responses to water availability of two co-occurring evergreen species. Annals of forest science 57(7), 623-633. doi:10.1051/forest:2000146.

Baker NR (2008) Chlorophyll Fluorescence: A Probe of Photosynthesis In Vivo. Annual Review of Plant Biology 59(1), 89-113. doi:10.1146/annurev.arplant.59.032607.092759.

Boureima S, Oukarroum A, Diouf M, Cisse N, Van Damme P (2012) Screening for drought tolerance in mutant germplasm of sesame (Sesamum indicum) probing by chlorophyll a fluorescence. Environmental and Experimental Botany 81, 37-43. doi:10.1016/j.envexpbot.2012.02.015.

Calatayud A, Roca D, Martínez PF (2006) Spatial-temporal variations in rose leaves under water stress conditions studied by chlorophyll fluorescence imaging. Plant Physiology and Biochemistry 44(10), 564-573. doi:10.1016/j.plaphy.2006.09.015.

Cannac M, Ferrat L, Barboni T, Chiaramonti N, Morandini F, Pasqualini V (2011) Identification of flavonoids in Pinus Laricio needles and changes occurring after prescribed burning. Chemoecology 21(1), 9-17. doi:10.1007/s00049-010-0060-4.

Cannac M, Pasqualini V, Barboni T, Morandini F, Ferrat L (2009) Phenolic compounds of Pinus laricio needles: A bioindicator of the effects of prescribed burning in function of season. Science of The Total Environment 407(15), 4542-4548. doi:10.1016/j.scitotenv.2009.04.035.

Damesin C (2003) Respiration and photosynthesis characteristics of current-year stems of Fagus sylvatica: from the seasonal pattern to an annual balance. New Phytologist 158(3), 465-475. doi:10.1046/j.1469-8137.2003.00756.x.

Do F, Rocheteau A (2002) Influence of natural temperature gradients on measurements of xylem sap flow with thermal dissipation probes. 1. Field observations and possible remedies. Tree Physiology 22(9), 641-648. doi:10.1093/treephys/22.9.641.

Ducrey M, Duhoux F, Huc R, Rigolot E (1996) The ecophysiological and growth responses of Aleppo pine (Pinus halepensis) to controlled heating applied to the base of the trunk. Canadian Journal of Forest Research 26(8), 1366-1374.

Ferrat L, Morandini F, Baconnais I, Silvani X, Berti L, Pasqualini V (2009) Impact of thermal stress on Pinus laricio: determining tolerance levels to prescribed burning through field experimentation. 
In 'Proceedings of the 24th Tall Timbers Fire Ecology Conference: The Future of Prescribed Fire: Public Awareness, Health, and Safety.', Tall Timbers Research Station, Tallahassee, Florida, USA. Pp 127-134. (K.M. Robertson, K.E.M. Galley, and R.E. Masters: Tall Timbers Research Station, Tallahassee, Florida, USA)

Ferrat L, Morandini F, Mascarenhas F, Elineau A, Cochard H, Poggi I (2011) Effects of prescribed burning on photosynthesis and water status of Pinus laricio. In 'Medpine 4: 4th International Conference on Mediterranean Pines.', Avignon, France.(Avignon, France)

Gielen B, Jach ME, Ceulemans R (2000) Effects of season, needle age, and elevated atmospheric CO2 on chlorophyll fluorescence parameters and needle nitrogen concentration in Scots pine (Pinus sylvestris). Photosynthetica 38(1), 13-21. doi:10.1023/A:1026727404895.

Gough CM, Seiler JR, Maier CA (2004) Short-term effects of fertilization on loblolly pine (Pinus taeda L.) physiology. Plant, Cell \& Environment 27(7), 876-886. doi:10.1111/j.13653040.2004.01193.x.

Granier A (1985) Une nouvelle méthode pour la mesure du flux de sève brute dans le tronc des arbres. Annales des Sciences Forestières 42(2), 193-200. doi:10.1051/forest:19850204.

Granier A, Gross P (1987) Mesure du flux de sève brute dans le tronc du Douglas par une nouvelle méthode thermique. Annales des Sciences Forestières 44(1), 1-14. doi:10.1051/forest:19870101.

Iijima Y, Ishikawa M, Suzuki K, Battogtokh D, Sharkhuu N, Kadota T, Ohata T (2004) Preliminary report of environmental regulation of xylem sapflow at the northern faced forest slope. In 'The third International Workshop proceedings on Terrestrial Change in Mongolia', Tsukuba, Japan. Pp 7881. (Tsukuba, Japan)

Köstner B, Biron P, Siegwolf R, Granier A (1996) Estimates of water vapor flux and canopy conductance of Scots pine at the tree level utilizing different xylem sap flow methods. Theoretical and Applied Climatology 53(1-3), 105-113. doi:10.1007/BF00866415.

Laing W, Greer D, Sun O, Beets P, Lowe A, Payn T (2000) Physiological impacts of Mg deficiency in Pinus radiata: growth and photosynthesis. New Phytologist 146(1), 47-57. doi:10.1046/j.14698137.2000.00616.x.

Lu P, Urban L, Zhao P (2004) Granier's thermal dissipation probe (TDP) method for measuring sap flow in trees: theory and practice. Acta Botanica Sinica 46(6), 631-646.

Maxwell K, Johnson GN (2000) Chlorophyll fluorescence - a practical guide. Journal of Experimental Botany 51(345), 659-668. doi:10.1093/jexbot/51.345.659.

Nasr Z, Mechlia NB (2007) Measurements of sap flow for apple trees in relation to climatic and watering conditions. In 'Water saving in Mediterranean agriculture and future research needs', Valenzano, Italy. Pp 91-98. (Valenzano, Italy)

Pasqualini V, Fernandez C, Giroud F, Bousquet-Mélou A, Cannac M, Ferrat L, Gauquelin T, Greff S, Guilmard M, Lavoir AV, Mevy JP, Picard C, Vila B (2009) Conséquence des brûlages dirigés sur le métabolisme primaire et secondaire de deux pins méditerranéens et relation avec les potentialités d'inflammation. Convention $\mathrm{n}^{\circ} \mathrm{E}$ 11.07.

Peñuelas J, Filella I, Llusia J, Siscart D, Piñol J (1998) Comparative field study of spring and summer leaf gas exchange and photobiology of the Mediterranean trees Quercus ilex and Phillyrea latifolia. Journal of Experimental Botany 49(319), 229-238. doi:10.1093/jxb/49.319.229.

Pukacki PM, Kamińska-Rożek E (2005) Effect of drought stress on chlorophyll a fluorescence and electrical admittance of shoots in Norway spruce seedlings. Trees 19(5), 539-544. doi:10.1007/s00468-005-0412-9.

Shangguan Z, Shao M, Dyckmans J (2000) Effects of Nitrogen Nutrition and Water Deficit on Net Photosynthetic Rate and Chlorophyll Fluorescence in Winter Wheat. Journal of Plant Physiology 156(1), 46-51. doi:10.1016/S0176-1617(00)80271-0.

Simpson DG (2000) Water use of interior Douglas-fir. Canadian Journal of Forest Research 30(4), 534-547. doi:10.1139/x99-233. 
Trabaud L (1979) Etude du comportement du feu dans la garrigue de chêne kermes à partir des températures et des vitesses de propagation. Annales des sciences forestières 36, 13-38. doi:10.1051/forest/19790102.

Vogg G, Heim R, Hansen J, Schäfer C, Beck E (1998) Frost hardening and photosynthetic performance of Scots pine (Pinus sylvestris L.) needles. I. Seasonal changes in the photosynthetic apparatus and its function. Planta 204(2), 193-200. doi:10.1007/s004250050246.

Zalesny Jr RS, Wiese AH, Bauer EO, Riemenschneider DE (2006) Sapflow of hybrid poplar (Populus nigra L. $\times$ P. maximowiczii A. Henry 'NM6') during phytoremediation of landfill leachate. Biomass and Bioenergy 30(8-9), 784-793. doi:10.1016/j.biombioe.2005.08.006. 